\title{
Management of a Rare Case: Transverse Testicular Ectopia Associated With Persistent Mullerian Duct Syndrome
}

\author{
Nadir Bir Olgunun Yönetimi: Kalııı Mülleryen Kanal Sendromu ile Ilişkili Transvers Testiküler \\ Ektopi
}

\author{
(1) Mehmet Semih Demirtaş${ }^{1}$, (1) Mustafa Tuşat² \\ ${ }^{1}$ Aksaray Training and Research Hospital, Clinic of Pediatrics, Aksaray, Turkey \\ ${ }^{2}$ Aksaray University Faculty of Medicine, Department of Pediatric Surgery, Aksaray, Turkey
}

\section{Abstract}

Transvers testiküler ektopi (TE), her iki testisin de aynı hemiskrotuma veya inguinal bölgeye migrasyonu ile karakterize erkek çocuklarda nadir görülen bir konjenital anomalidir. TE olgularına, müllerian kanal yapılarının varlığı ile birlikte fenotipik olarak erkek olan, karakterize kalıcı müllerian kanal sendromu eşlik eder. Persistan Müllerian kanal sendromu, anti-müllerian hormonun veya reseptörünün genetik kusurundan kaynaklanır. Bu olguda, sağ kasıkta şişlik ve palpe edilemeyen sol testis ile başvuran 12 yaşında bir erkek çocukta persistent müllerian duktus sendromu ile ilişkili bir transvers testis ektopisi bildirdik. Hasta fıtık kesesinin yüksek ligasyonu, müllerian yapıların eksizyonu ve transseptal orşiopeksi ile tedavi edildi. Olguların cerrahi yaklaşımında, testislere ve diğer komşu yapılara zarar vermeden, müllerian yapıların mümkün olduğunca çıkarılması ve testislerin palpe edilebilmesi gerektiğini düşünüyoruz.

Anahtar Kelimeler: Transvers Testiküler Ektopi, Persistent Müllerian Kanal Sendromu, İnguinal Herni, İnmemiş Testis, Transseptal Orşiopeksi

Öz

Transverse testicular ectopia (TTE) is a rare congenital anomaly in boys, which is characterized by the migrate of both testicles towards the same hemiscrotum or inguinal region. TE cases are accompanied by the characterized persistent mullerian duct syndrome, which is phenotypically male, with the presence of mullerian duct structures. Persistent Müllerian duct syndrome is caused either by the genetic defect of the anti-mullerian hormone or its receptor. In this case, we reported a TE associated with persis-tent mullerian duct syndrome in a 12-year-old boy who presented with swelling in the right groin and non-palpable left testis. The patient was treated with high ligation of the hernia sac, excision of mullerian structures and transseptal orchiopexy. In the surgical approach of the cases, we think that removing the mullerian structures as much as possible and making the testicles palpable without damaging the testicles and other adjacent structures are important.

Key Words: Transverse Testicular Ectopia, Persistent Mullerian Duct Syndrome, Inguinal Hernia, Undescended Testis, Transseptal Orchiopexy

\section{Introduction}

Transverse testicular ectopia is a rare congenital anomaly in which both the testis migrates ipsilaterally towards the same hemiscrotum. As a result, both testicles can be found in the deep inguinal canal or hemiscrotum on the same side (1).
Persistent mullerian duct syndrome is a rare type of hermaphroditism characterized by the presence of mullerian structures such as the uterus, tuba uterina and the upper third of the vagina in a boy with a completely normal appearance. Transverse testicular ectopia (TE) and persistent müllerian duct syndrome (PMDS) coexist very rarely and 57 cases have been

Address for Correspondence/Yazışma Adresi: Mehmet Semih Demirtaş

Aksaray Training and Research Hospital, Clinic of Pediatrics, Aksaray, Turkey

Phone: +90 3825201020 E-mail: md.semihdemirtas@gmail.com ORCID ID: orcid.org/0000-0003-2965-1811

Received/Geliş Tarihi: 13.10.2020 Accepted/Kabul Tarihi: 12.01.2021

๑Copyright 2021 Ankara University Faculty of Medicine

Journal of Ankara University Faculty of Medicine is published by Galenos Publishing House.

All content are under CC BY-NC-ND license. 
reported so far (2). We report a case of TTE associated with PMDS applied to clinic with swelling in the right groin and left non-palpable testis.

\section{Case Report}

A 12-year-old foreign male patient was referred from the pediatric outpatient clinic to the pediatric surgery department due to the absence of left testicle and swelling in the right groin for the last 6 months. Swelling increased when coughing or carrying heavy objects. On examination, the patient had normal secondary sexual characteristics with a male pattern of external genitalia. There was the silk glove sign in right inguinal region. The left side of the scrotum was undeveloped. Left testis was not palpable and two $2 \times 2.5 \mathrm{~cm}$ masses suspected of having testicles in the right scrotum of the patient were palpated. Afterwards, it was confirmed by ultrasonography (USG) that both testicles were in the right scrotum. One of them was in high scrotal location and our pre-diagnosis was TE. In USG imagination revealed a right inguinal hernia and the testis at the base of the right hemiscrotum was measured $29 \times 22 \mathrm{~mm}$ in size while the high-placed testis was measured as $29 \times 26 \mathrm{~mm}$ in the right hemiscrotum. The vas deferens and vascular structures belonging to each testis were observed. The parenchyma of both testicles was homogeneous. No structure was seen in the left scrotum. There was a suspicious cystic structure behind the bladder. No other urologic anomalies were identified. Magnetic resonance imaging also revealed same findings. Moreover, the uterus-like cystic structure was observed on the right side of the bladder with a size of $30 \times 15 \mathrm{~mm}$ and its extension was observed in the right inguinal canal (Figure 1). Serum follicle stimulating hormone, luteinizing hormone, prolactin testosterone and dihydrotestosterone (DHT) levels were normal while antiMullerian hormone $(A M H)>24.20 \mathrm{ng} / \mathrm{mL}(0.73-16.05 \mathrm{ng} / \mathrm{mL})$ was found. Karyotype analysis of the patient was reported as $46, \mathrm{XY}$. Detailed information about the current diagnosis and treatment was given to the family of the patient. Signature was obtained for the informed consent form from the family. The patient was

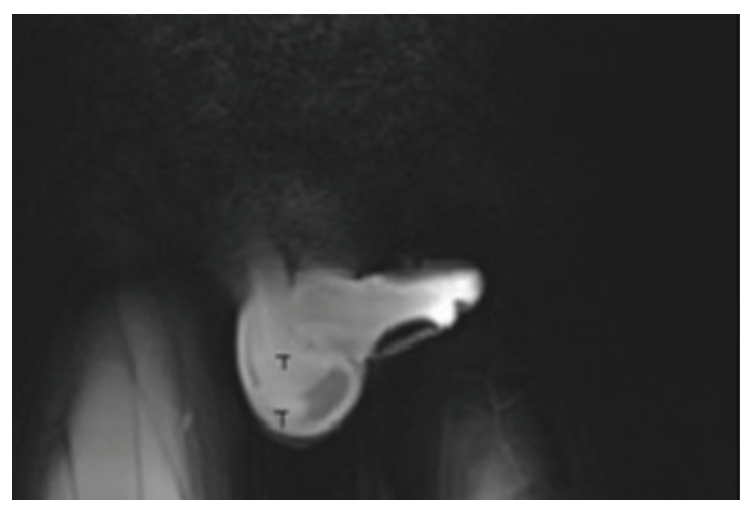

Figure 1: MRI of the pelvis and abdomen of patient

MRI: Magnetic resonance imaging operated with the pre-diagnosis of the right inguinal hernia and TE associated with PMDS. Both gonads, their cord and vascular structures, and rudimentary structures of the mullerian ducts delivered from the incisional wound after right inguinal exploration was done. Both gonads macroscopically were testes and their dimensions $(3 \times 2.5 \mathrm{~cm})$ were similar. Each testicle had a normal appearance with the epididymis, vas deferens and testicular vessels separated. Both spermatic cords in close relation with a rudimentary uterus and bilateral fallopian tube were seen to enter the abdomen through the right deep inguinal ring. An rudimentary uterus and bilateral fallopian tube with fimbria were seen between both testicles (Figure 2). Uterus and fallopian tubes were carefully dissected from the testicles, vas deferenses and vascular structures (Figure 2). Later, the hernial sac was separated carefully and a inguinal hernia repair was performed. All mullerian structures was removed completely and sent for histopathology (Figure 2). Per-operative biopsies were taken from each testis. Testicular biopsies were reported as testicular tissue, while rudimentary structure was reported as uterus with inactive endometrium with bilateral fallopian tubes and cervix. Left testicle was brought down to the left hemiscrotum transseptally via the right inguinoscrotal canal. Then, the right testis was placed and fixed on the pouch of the right hemiscrotum scrotum, and transseptal orchiopexy was completed (Figure 3). The patient, who had no complications in the postoperative period, was called to the outpatient clinic and discharged. In the examination of the patient who came to the outpatient clinic, no pathological examination finding was found, and abdominal and pelvic USG imaging was also found to be normal.

\section{Discussion}

TTE with unknown etiology has been classified into three types: Type 1 associated with only inguinal hernia (40-50\%), type 2 accompanied by PMDS (20-30\%), and type 3 associated with other anomalies such as hypospadiasis, pseudohermaphroditism and scrotal abnormality (1-3). The ectopic testis may be located

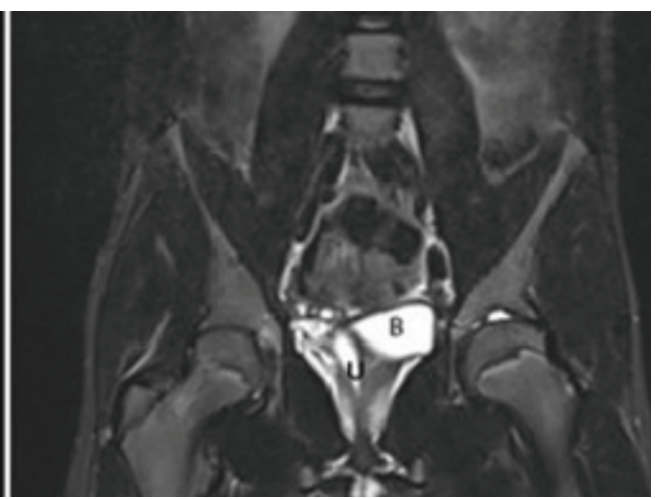




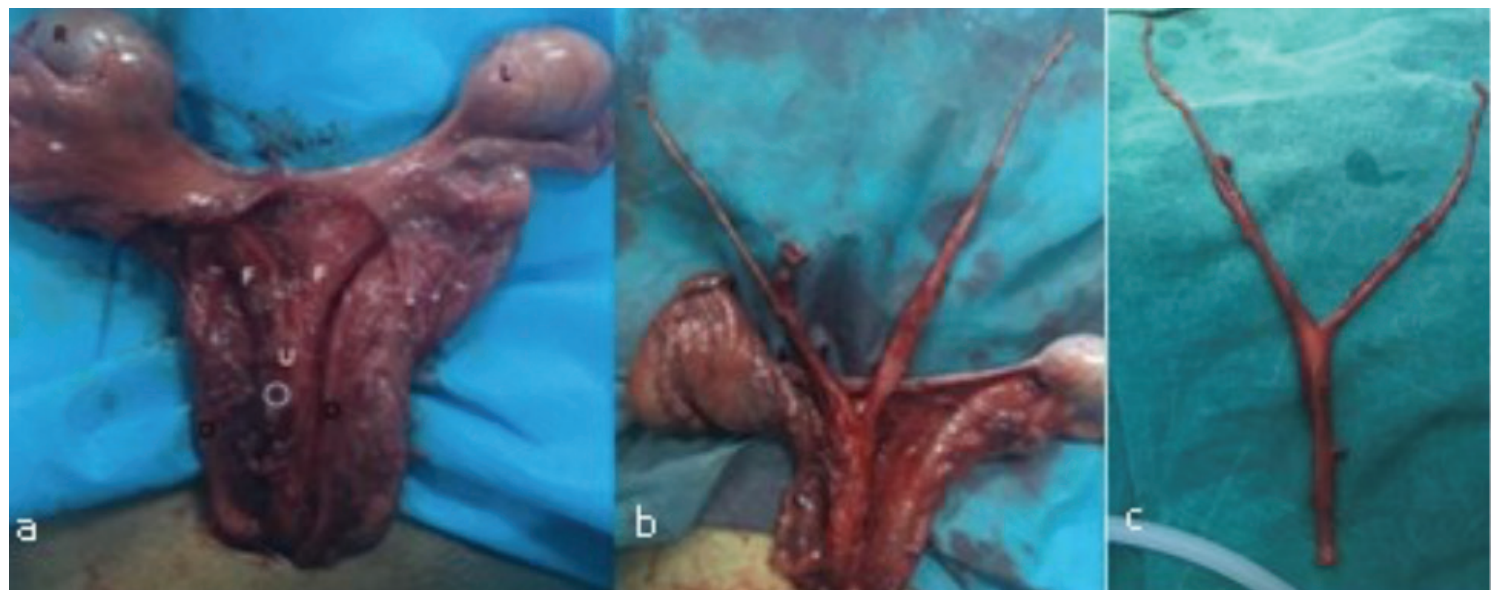

Figure 2: Intraoperative view of the mullerian remnants and testes, dissection of rudimentary duct structures, excised specimen
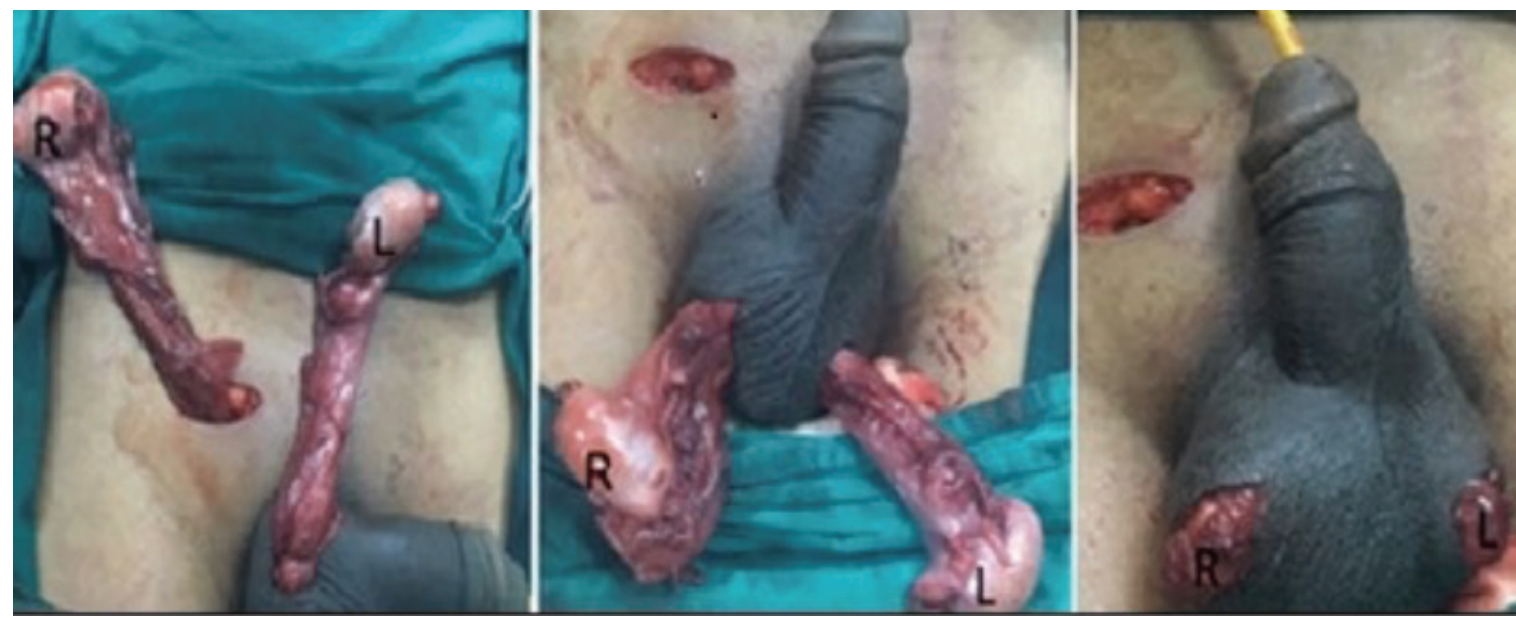

Figure 3: Stages of transseptal orchiopexy

in the abdomen, at the level of the internal inguinal ring or in the same hemiscrotum. TTE is often accompanied by ipsilateral inguinal hernia and contralateral non-palpable testicle $(1,3,4)$.

Sexual differentiation is controlled by testosterone and AMH. PMDS mainly due to two causes: Failure of AMH secretion, end organ resistance to $\mathrm{AMH}$. Since serum testosterone and DHT remain within normal range, patients with PMDS are phenotypically and genotypically males with normal secondary sexual characteristics (5). In TE cases accompanied by PMDS, the diagnosis is usually made by seeing the rudimentary uterus and fallopian tubes during the operation of undescended testis or inguinal hernia (6). Although ultrasonography is helpful for diagnosis, it is not a good imaging method in intraabdominally located testicles. MR is the best non-invasive method for detecting intraabdominal testes and mullerian residues $(3,6,7)$.

The mixed gonadal dysgenesis (MGD) is the most important disease to consider in the differential diagnosis of PMDS. Since $\mathrm{AMH}$ and testosterone secretion are also impaired in $M G D$, there are both mullerian canal residues and disorders in external genitalia. In addition, patients with MGD generally have karyotype of $46 \mathrm{XO}$ or $46 \mathrm{XY}$ (8). In our case, the result of karyotype analysis was reported as $46 \mathrm{XY}$. Testosterone, follicle stimulating hormone, luteinising hormone and prolactin levels measured to support differential diagnosis were normal.

The best surgical approach in TTE cases with PMDS is excision of mullerian rudiments, orchiopexy with inguinal hernia repair, or orchidectomy when necessary and the operation should include the biopsy of both testicles $(1,6)$. Transseptal orchiopexy technique is generally used in TTE surgical treatment. In this technique, the testis with a longer spermatic cord is placed in the subdartos pouch on the opposite side, while the other testis is placed on the same side. In bilateral orchiopexy, each testis is passed through a separate inguinal incision through a separate inguinal canal. In order to perform this technique, testicular vessels and vas deferens should be of sufficient length $(2,6)$.

Some authors do not recommend removing the mullerian ducts because of the risk of damage to the vas deferens and vascular structures and the low rate of malignancy from 
mullerian residues. However, recent studies have revealed that the left mullerian remains have a malignant potential $(2,6,9)$. Therefore, we removed all the mullerian structures in our case. In addition, many testicular tumors such as seminoma, choriocarcinoma, embryonal carcinoma and teratoma have been reported in PMDS patients with undescended testicles $(2,10)$. The postoperative follow-up period of the patient was specified and It was decided to follow the patient at regular intervals of 6 months. Although virilization is usually normal in patients with PMDS, almost all patients are infertile (10).

As a conclusion, in cases of TTE with PMDS, The case management requires that the condition is recognized by the surgeon and verified by biochemical testing, radiological imagination, testicular biopsies and chromosomal studies. In the surgical approach of the cases, we think that removing the mullerian structures and their attachments as much as possible and making the testicles palpable without damaging the testicles and other adjacent structures.

\section{Ethics}

Informed Consent: Signature was obtained for the informed consent form from the family.

Peer-reviewed: Externally peer-reviewed.

\section{Authorship Contributions}

Surgical and Medical Practices: M.T., Concept: M.S.D., Design: M.S.D., Data Collection or Processing: M.S.D., Analysis or Interpretation: M.S.D., M.T., Literature Search: M.T., Writing: M.S.D., M.T.
Conflict of Interest: The authors declare no conflict of interest.

Financial Disclosure: The authors disclose that they received no financial support for this work.

\section{References}

1. Abdullayev T, Korkmaz M. Transvers testicular ectopia: A case report and literature review. Int J Surg Case Rep. 2019;65:361-364.

2. Rajesh A, Farooq M. A rare case of male pseudohermaphroditism-persistent mullerian duct syndrome with transverse testicular ectopia - Case report and review of literature. Int J Surg Case Rep. 2017;37:72-75.

3. Alamsahebpour A, Blachman-Braun R, Gupta A, et al. Laparoscopy and transseptal orchiopexy in the management of transverse testicular ectopia. Curr Urol Rep. 2015;16:48.

4. Akin $M$, Erginel B, Bilici $S$, et al. Crossed testicular ectopia: Report of six cases. Afr J Paediatr Surg. 2014;11:269-272.

5. Shalaby MM, Kurkar A, Zarzour MA, et al. The management of the persistent Müllerian duct syndrome. Arab J Urol. 2014;12:239-244.

6. Cansaran S, Moralioglu S, Celayir A, et al. Management of Transverse Testicular Ectopia with Persistent Mullerian Duct Syndrome. North Clin Istanb. 2018;5:357-360.

7. Singh R, Kumar SD, Aggarwal N. MRI findings of Persistent Mullerian Duct Syndrome: A Rare Case Report. J Clin Diagn Res. 2017;11:TD05-TD06.

8. Saikia UK, Sarma D, Das DV, et al. A Case of Mixed Gonadal Dysgensis: A Diagnostic Challenge. J Hum Reprod Sci. 2019;12:169-172.

9. Mukhtar MU, Niazi SAK, Sarwar MZ, et al. Transverse testicular ectopia with persistent Mullerian duct syndrome: an operative eureka. Int J Surg Case Rep. 2020;71:338-340.

10. Romero FR, Fucs $M$, Castro $M G$, et al. Adenocarcinoma of persistent müllerian duct remnants: case report and differential diagnosis. Urology. 2005;66:194-195. 